\title{
Bezdzietna kobieta w wieku 21 lat z zatorowością płucną - leczenie w dobie nowych doustnych antykoagulantów
}

\author{
Pulmonary embolism in 21-year-old childless woman \\ - treatment in the area of new oral anticoagulants
}

\author{
Marta Drankowska, Elżbieta Malarkiewicz, Agnieszka Słowińska
}

Oddział Kardiologii z Oddziałem Intensywnego Nadzoru Kardiologicznego Wojewódzkiego Szpitala Specjalistycznego w Olsztynie

\section{Streszczenie}

Zatorowość płucna (PE) jest stanem nagłym wymagającym szybkiej diagnostyki i niezwłocznego wdrożenia terapii. Podstawowym leczeniem PE są leki przeciwkrzepliwe - zarówno podawane parenteralnie, jak i doustnie. W leczeniu początkowym stosuje się heparyny (frakcjonowane lub drobnocząsteczkowe), a następnie leki doustne. Coraz częściej leczenie jest kontynuowane nowymi doustnymi antykoagulantami (NOAC), które skutecznością dorównują antagonistom witaminy $\mathrm{K}$, a nie wymagają monitorowania międzynarodowego współczynnika znormalizowanego. Obecnie, ze względu na brak randomizowanych badań, nie zaleca się stosowania NOAC u kobiet w ciąży. W niniejszej pracy autorki zastanawiają się nad wyborem sposobu leczenia u młodej bezdzietnej kobiety w wieku rozrodczym z rozpoznaną PE.

Słowa kluczowe: NOAC, zatorowość płucna

Folia Cardiologica 2017; 12, 3: 291-294

\section{Wstęp}

Zatorowość płucna (PE, pulmonary embolism) jest stanem nagłym wymagającym szybkiej diagnostyki i niezwłocznego wdrożenia decyzji terapeutycznych. Nie jest to łatwe ze względu na niespecyficzne objawy, które należy różnicować z innymi chorobami układu sercowo-naczyniowego i płuc. Rozpoznawalność jest nadal niska, a wczesna śmiertelność wysoka, sięgająca 15\% w grupie pacjentów z PE wysokiego ryzyka, 3-15\% - w grupie pośredniego ryzyka i 0-1\% - w grupie niskiego ryzyka. Zgodnie z wytycznymi Europejskiego Towarzystwa Kardiologicznego (ESC, European Society of Cardiology)/Polskiego Towarzystwa Kardiologicznego wstępny okres diagnostyki powinien obejmować ocenę ciężkości i klinicznego prawdopodobieństwa PE. Kryterium ciężkości dla PE wysokiego ryzyka stanowią objawy wstrząsu i hipotensji. Kryterium dla PE niewysokiego, pośredniego ryzyka są cechy dysfunkcji prawej komory lub obecność markerów uszkodzenia mięśnia sercowego, natomiast brak takich cech przemawia za PE niskiego ryzyka. Ocena prawdopodobieństwa klinicznego obejmuje wywiad dotyczący objawów i czynników ryzyka żylnej choroby zakrzepowo-zatorowej (VTE, venous thromboembolism) oraz badanie przedmiotowe. Testy służące potwierdzeniu lub wykluczeniu PE to arteriografia płucna, angiografia tomografii komputerowej (angio-CT, computed tomography angiography) klatki piersiowej, scyntygrafia wentylacyjno-perfuzyjna płuc, echokardiografia przez ścianę klatki piersiowej i echokardiografia przezprzełykowa oraz oznaczenie stężenia D-dimeru.

Leki przeciwkrzepliwe są podstawą leczenia i prewencji chorób zakrzepowo-zatorowych. Obecnie do leczenia ostrych stanów zakrzepowo-zatorowych, często w warunkach szpitalnych, stosuje się leki podawane pozajelitowo,

Adres do korespondencji: lek. Marta Drankowska, Oddział Kardiologii z Oddziałem Intensywnego Nadzoru Kardiologicznego, Wojewódzki Szpital Specjalistyczny w Olsztynie, ul. Żołnierska 18, 10-561 Olsztyn, e-mail: martadrankowska@o2.pl 
natomiast do długotrwałej antykoagulacji wykorzystuje się leki doustne (pochodne kumaryny). Przez ostatnie ponad 65 lat jedynymi dostępnymi doustnymi antykoagulantami były leki z grupy antagonistów witaminy $\mathrm{K}$ (VKA, vitamin $\mathrm{K}$ antagonists), takie jak warfaryna czy acenokumarol. Leki te są skuteczne w prewencji i leczeniu VTE, w prewencji zatorowości kardiogennej w krążeniu dużym (np. w migotaniu przedsionków i zastawkowych wadach serca). Leki te mają jednak poważne ograniczenia, takie jak interakcje z innymi lekami i pokarmem, prowadzące do zmiennej aktywności antykoagulacyjnej, co z kolei powoduje konieczność częstego monitorowania krzepliwości krwi, co może być uciążliwe i stresujące zarówno dla chorego, jak i lekarza. Generuje to także więcej wizyt kontrolnych u lekarza podstawowej opieki zdrowotnej (POZ), a co za tym idzie - dłuższe kolejki do poradni. Dlatego istnieje zapotrzebowanie na leki alternatywne do VKA, które można by stosować doustnie bez konieczności monitorowania efektu antykoagulacyjnego. Spowodowało to podjęcie badań nad stworzeniem drobnocząsteczkowych substancji, aktywnych po podaniu doustnym, działających swoiście na określone enzymy układu krzepnięcia. Od kilku lat jest na rynku dostępny riwaroksaban - inhibitor czynnika Xa, który skutecznością dorównuje VKA, a nie wymaga przewlekłego monitorowania międzynarodowego współczynnika znormalizowanego (INR, international normalized ratio).

\section{Opis przypadku}

Kobieta w wieku 21-lat z przetrwałym otworem owalnym (PFO, patent foramen ovale) w wywiadzie, nielecząca się dotychczas z powodu chorób przewlekłych, została przywieziona na szpitalny oddział ratunkowy (SOR) przez zespół ratownictwa medycznego z powodu dyskomfortu oraz uczucia ucisku w klatce piersiowej z towarzyszącą dusznością trwających od 3 dni. Objawy pojawiły się po raz pierwszy w życiu. Ostatniej nocy dolegliwości się nasiliły, a rano w dniu przyjęcia nastąpiło krótkotrwałe omdlenie w obecności matki pacjentki.

W wywiadzie stwierdzono przyjmowanie doustnych leków antykoncepcyjnych od około 2 lat, niepalenie tytoniu i okazjonalne spożywanie alkoholu; wywiad rodzinny nie był obciążający. Przy przyjęciu stan ogólny pacjentki był średni, z zachowanym kontaktem słowno-logicznym i dusznością spoczynkową. Skóra chorej była blada i spocona. Osłuchowo stwierdzono zaostrzony szmer pęcherzykowy, miarową czynność serca, tachykardię 120/min i brak szmerów patologicznych. Ciśnienie tętnicze wynosiło 130/80 mm Hg. Kończyny dolne nie nosiły cech obrzęków ani żylaków. Pacjentka miała nadwagę.

W wykonanych na SOR badaniach laboratoryjnych spośród odchyleń od normy stwierdzono: leukocytozę 15,2 $\times$ $\times 10^{3} / \mu \mathrm{l}$, liczbę granulocytów $11,2 \times 10^{3} / \mu$ l, liczbę monocytów $1,1 \times 10^{3} / \mu$ l, stężenie białka C-reaktywnego (CRP,
C-reactive protein) - 4,75 mg/dl, czas częściowej tromboplastyny po aktywacji (APTT, activated partial prothrombin time) - 23,6 s, stężenie D-dimeru 12,0 $\mu \mathrm{g} / \mathrm{dl}$. W gazometrii (krew włośniczkowa) pH wynosiło 7,47. Na podstawie wywiadu, badania przedmiotowego oraz wyników badań dodatkowych poszerzono diagnostykę o badanie angio-CT klatki piersiowej, w którym uwidoczniono obecność masywnych skrzeplin obustronnie w okolicy podziałów prawej i lewej tętnicy płucnej oraz dalej w ich rozgałęzieniach płatowych, segmentalnych i subsegmentalnych - skrzepliny zajmowały do 3/4 światła wyżej wymienionych tętnic płucnych. W badaniu echokardiograficznym nie było cech przeciążenia prawego serca, ani znamiennego skrócenia czasu akceleracji przepływu płucnego; ciśnienie skurczowe w prawej komorze było nieznacznie podwyższone.

Włączono leczenie PE zgodne ze standardami. W 2. dobie pobytu pobrano krew do badań (białka C i S, antytrombina III, fibrynogen, czynnik V Leiden). Spośród odchyleń od normy stwierdzono mutację czynnika V Leiden. Wykonano badanie ultrasonograficzne (USG) metodą Dopplera żył kończyn dolnych, w którym uwidoczniono zmiany zakrzepowe w dystalnym (trudno dostępnym badaniu) odcinku prawej żyły udowej - żyła była słabo podatna na kompresje, z przyścienną rekanalizacją, a w jej proksymalnym odcinku oraz żyle podkolanowa i głębokiej goleni nie stwierdzono zmian zakrzepowych. W jednoimiennych żyłach po lewej stronie również nie było zmian zakrzepowych.

W 2. dobie hospitalizacji włączono riwaroksaban w dawce 2 razy $15 \mathrm{mg}$. W godzinach wieczornych obserwowano u chorej krwawienie z nosa; była konsultowana laryngologicznie i zalecono dalszą obserwację. W toku dalszej obserwacji stan pacjentki uległ stopniowej poprawie - duszność zmniejszyła się i nie była już konieczna stała tlenoterapia ze względu na $\mathrm{SatO}_{2}$ wynoszącą 97-98\% bez wspomagania tlenem. W 8. dobie hospitalizacji wykonano kontrolne angio-CT klatki piersiowej, w którym uwidoczniono częściową regresję ilości materiału zatorowego w naczyniach płucnych. Pacjentkę w dobrym stanie ogólnym wypisano do domu z zaleceniem kontroli w poradni chirurgii naczyniowej i kontrolnego USG metodą Dopplera żył kończyn dolnych. Zalecono przyjmowanie riwaroksabanu w dawce 2 razy $15 \mathrm{mg}$ przez kolejne 2 tygodnie, następnie $20 \mathrm{mg}$ raz na dobę.

\section{Terapia riwaroksabanem — jak długo?}

Jak wspomniano, pacjentkę w dobrym stanie ogólnym wypisano do domu z zaleceniem leczenia przeciwkrzepliwego riwaroksabanem. Podczas końcowej rozmowy z nią padło pytanie, jak długo będzie musiała przyjmować leki.

Pacjentka była obciążona dwoma czynnikami ryzyka - stosowała doustną antykoncepcję i występowała u niej mutacja czynnika V Leiden. Pierwszy czynnik ryzyka jest modyfikowalny - zalecono odstawienie środków antykon- 
cepcyjnych, natomiast mutacja czynnika V Leiden niesie za sobą dożywotnie zwiększone ryzyko rozwoju chorób zakrzepowo-zatorowych. Ponadto PFO wiąże się z ryzykiem zatorowości skrzyżowanej, która może się zamanifestować jako udar niedokrwienny mózgu lub napad przemijającego niedokrwienia mózgu (TIA, transient ischemic attack). Dlatego tej pacjentce zalecono dożywotnie stosowanie leków przeciwkrzepliwych.

Czynniki ryzyka VTE podsumowano w tabeli 1.

Tabela 1. Czynniki ryzyka żylnej choroby zakrzepowo-zatorowej (w tym zatorowości płucnej)

Cechy osobnicze i stany kliniczne
Wiek > 40 lat (ryzyko wzrasta z wiekiem)
Otyłość (wskaźnik masy ciała > $30 \mathrm{~kg} / \mathrm{m}^{2}$ )
Zakrzepica lub zatorowość płucna w wywiadzie rodzinnym
Urazy (zwłaszcza wielonarządowe lub złamania)
Niedowład kończyn dolnych, długotrwałe unieruchomienie
Nowotwory złośliwe (ryzyko wzrasta wraz zaawansowaniem
nowotworu)
Przebyta zakrzepica
Trombofilia wrodzona lub nabyta
Sepsa
Obłożna choroba leczona zachowawczo (np. ciężkie zapalenie
płuc)
Niewydolność serca
Niewydolność oddechowa
Choroby jelit: choroba Leśniowskiego-Crohna, wrzodziejące
zapalenie jelita grubego
Zespół nerczycowy
Choroby szpiku kostnego (tzw. zespoły mieloproliferacyjne)
Nocna napadowa hemoglobinuria
Ucisk na naczynia żylne
Ciąża i połóg
Długotrwały lot samolotem
Żylaki kończyn dolnych
Zabiegi diagnostyczne, lecznicze i profilaktyczne

Duże zabiegi operacyjne, szczególnie w obrębie kończyn dolnych, miednicy i jamy brzusznej

Obecność cewnika w dużych żyłach

Leczenie przeciwnowotworowe - chemioterapia, leczenie hormonalne

Stosowanie doustnych środków antykoncepcyjnych i/lub hormonalnej terapii zastępczej

Stosowanie leków stymulujących erytropoezę (czyli powstawanie krwi w szpiku kostnym)

\section{Omówienie}

Czy u tak młodej pacjentki w okresie rozrodczym należy stosować leki przeciwkrzepliwe? Jak powinna planować ewentualne zajście w ciążę? Istnieją dowody na to, że obecność mutacji Leiden może się wiązać z niepowodzeniami położniczymi. W wytycznych American College of Obstetricians and Gynecologists (ACOG) podano dwie grupy ryzyka zakrzepowego związanego z wrodzoną trombofilią. W grupie dużego ryzyka, do której należy homozygotyczna postać mutacji Leiden, u bezobjawowych do tej pory pacjentek w ciąży zaleca się profilaktykę przeciwzakrzepową z zastosowaniem heparyn drobnocząsteczkowych (LMWH, low-molecular-weight heparin) w okresie ciąży i VKA przez 4-6 tygodni po ciąży. W tej samej grupie u pacjentek po przebytym epizodzie VTE zaleca się LMWH w dawce profilaktycznej lub pośredniej w okresie ciąży i leczenie za pomocą VKA przez 6 tygodni po ciąży. Do grupy małego ryzyka należą nosicielki postaci heterozygotycznej mutacji czynnika V. W tej grupie u pacjentek, u których dotychczas nie wystąpiły epizody zatorowe, zaleca się baczną obserwację lub profilaktykę przeciwzakrzepową - zarówno przed ciążą, jak i po niej. Natomiast heterozygoty po przebytym epizodzie, cechujące się małym ryzykiem, powinny być w czasie ciąży uważnie obserwowane lub powinno się u nich stosować LMWH, a po ciąży zaleca się podawanie leków przeciwkrzepliwych przez 4-6 tygodni. Kobiety ciężarne z trombofilią, u których istnieją wskazania do stosowania leków przeciwkrzepliwych, powinny rozpoczynać terapię już w I trymestrze ciąży. U pacjentek z tego rodzaju zaburzeniami krzepnięcia częściej niż u pozostałych wykonuje się kontrolne badanie ultrasonograficzne (USG). W przypadku trombofilii nie zaleca się cięcia cesarskiego, a wręcz przeciwnie - takim pacjentkom lekarze doradzają, aby rodziły siłami natury, jeśli oczywiście jest to możliwe. To rozwiązanie jest dużo bardziej bezpieczne dla matki.

Omawiając aspekty profilaktyki przeciwzakrzepowej u kobiet w ciąży z wrodzoną trombofilią, należy dodać, że nadal brakuje danych na temat bezpiecznego stosowania w okresie ciąży NOAC. Podobnie jak w przypadku warfaryny i acenokumarolu, nie zaleca się stosowania bezpośrednich inhibitorów trombiny (dabigatran) ani inhibitorów czynnika Xa (riwaroksaban i apiksaban). Leki te, ze względu na swoją małą masę cząsteczkową, prawdopodobnie mogą przenikać przez łożysko. Wobec coraz szerszego stosowania nowych doustnych antykoagulantów (NOAC, new oral anticoagulants) należy się także zastanowić, jakie ryzyko niesie za sobą narażenie płodu we wczesnym okresie ciąży jeszcze przed jej stwierdzeniem u pacjentek przewlekle leczonych przeciwkrzepliwie.

Autorki niniejszego opracowania znalazły jedną prace z German Embryotox Pharmacovigilance Centre na temat 
riwaroksabanu stosowanego we wczesnej ciąży. Analizowane w tej pracy przypadki nie dostarczają dowodów toksycznego działania tego leku na płód, ale też nie są to wystarczające dane o bezpieczeństwie jego stosowania. Autorzy wspomnianej pracy podtrzymują stanowisko, że NOAC nie powinny być stosowane w czasie ciąży. Wobec braku jednoznacznych przeciwwskazań, ale także z powodu niewykluczonych potencjalnych działań niepożądanych, wydaje się być stosowne ostrożne stosowanie riwaroksabanu u kobiet w wieku rozrodczym, a w przypadku wybrania NOAC jako metody leczenia stosowanie metody antykoncepcyjnej o wysokiej skuteczności (systemy transdermalne, pigułki antykoncepcyjne).

\section{Konflikt interesów}

Autorki nie deklarują konfliktu interesów

\section{Abstract}

Pulmonary embolism (PE) is an acute condition that requires rapid diagnosis and immediate treatment. Basic treatment of PE is anticoagulant - both parenteral and oral. In initial treatment heparin (fractionated or low-molecular weight) is used, followed by oral medications. More and more often treatment is continued with new oral anticoagulants (NOAC), which are as effective as vitamin antagonists $\mathrm{K}$, but do not need to monitor the international normalized factor. Currently, due to lack of randomized studies, NOAC is not recommended for pregnant women. In this paper the authors are pondering over the choice of treatment method in young childbearing woman of childbearing age with recognized PE.

Key words: NOAC, pulmonary embolism

Folia Cardiologica 2017; 12, 3: 291-294

\section{Piśmiennictwo}

1. Bednarz B, Biederman A, Budaj A. Zakrzepy i zatory. Wydawnictwo Lekarskie PZWL, Warszawa 2014.

2. Chan WS, Rey E, Kent N, et al. Society of Obstetricians and Gynecologists of Canada. Venous thromboembolism and antithrombotic therapy in pregnancy. J Obstet Gynaecol Can. 2014; 36(6): 527-553, indexed in Pubmed: 24927193.

3. Dahlman TC, Hellgren M, Blombäck M. Thrombosis prophylaxis in pregnancy with use of subcutaneous heparin adjusted by monitoring heparin concentration in plasma. Am J Obstet Gynecol. 1989; 161(2): 420-425, indexed in Pubmed: 2764060.

4. Frołow M. Kto jest zagrożony zakrzepicą? https://zakrzepica.mp.pl/ /wszystkoozakrzepicy/profilaktyka/55428,kto-jest-zagrozony-zakrzepica. (July $\left.27^{\text {th }} 2016\right)$.
5. Hoeltzenbein M, Beck E, Meixner K, et al. Pregnancy outcome after exposure to the novel oral anticoagulant rivaroxaban in women at suspected risk for thromboembolic events: a case series from the German Embryotox Pharmacovigilance Centre. Clin Res Cardiol. 2016; 105(2): 117-126, doi: 10.1007/s00392-015-0893-5, indexed in Pubmed: 26195125.

6. Karthikeyan G, Eikelboom JW, Hirsh J. Nowe doustne antykoagulanty - jeszcze nie koniec drogi. Pol Arch Med Prakt. 2000; 119(1-2): 1-6.

7. Szczeklik A, Gajewski P. Interna Szczeklika 2015. Podręcznik chorób wewnętrznych. Wyd. 7. Medycyna Praktyczna, Kraków 2015. 